\title{
Is there Really no Conglomerate Discount?*
}

\author{
Manuel Ammann ${ }^{\mathrm{a}}$, Daniel Hoechle ${ }^{\mathrm{b}, \mathrm{c}}$, Markus Schmid ${ }^{\mathrm{d}, \#}$ \\ ${ }^{a}$ Swiss Institute of Banking and Finance, University of St. Gallen, CH-9000 St. Gallen, \\ Switzerland \\ ${ }^{b}$ Department of Finance, University of Basel, CH-4051 Basel, Switzerland \\ ${ }^{c}$ Man Investments, Pfaeffikon, $\mathrm{CH}-8808$, Switzerland \\ ${ }^{d}$ University of Mannheim, Finance Area, D-68131 Mannheim, \\ Germany
}

This version: August 2011

\begin{abstract}
Recent research questions the existence of a conglomerate discount. This study addresses two of the most important explanations for the conglomerate discount and finds evidence in support of an economically and statistically significant discount. The first explanation is that the risk-reducing effect of diversification increases debt value and consequently the use of the book value of debt leads to an underestimation of firm value in diversified firms. We show that the effect of using an imputed market value of debt reduces the conglomerate discount only by a small fraction. However, consistent with the value-transfer hypothesis, we find the discount to increase in leverage and no discount for all-equity firms. An agency cost-based explanation, which reconciles these conflicting findings, is that managers in levered firms become aligned with creditors and reduce firm risk at the expense of shareholders. Hence, the diversification discount only occurs in levered firms and stems from conflicts of interest between managers and shareholders over corporate risk taking. Second, the conglomerate discount may emerge from a neglect of the endogenous nature of the diversification decision. We first show that the conglomerate discount in fact disappears when we account for endogeneity in a Heckman selection model. However, when we account for fixed effects, the conglomerate discount remains statistically and economically significant, also in a Heckman selection-model or instrumental variables framework.
\end{abstract}

Keywords: Organizational structure; Diversification; Market value of debt; Endogeneity; Fixed effects

JEL Classification: G32, G34

* We are grateful to an anonymous referee, Yakov Amihud, Aswath Damodaran, Markus Glaser, Gunnar Grass, David Oesch, Urs Peyer, Peter Pope (the editor), Nagpurnanand Prabhala, Stephan Suess, Gabrielle Wanzenried, Marco Wilkens, Evert Wipplinger, and seminar participants at the University of Bayreuth, the University of St. Gallen, the 2008 Conference of the Swiss Society for Financial Market Research in Zurich, and the 2008 Symposium on Finance, Banking, and Insurance at the University of Karlsruhe for helpful comments and discussions. All errors are our own.

"Corresponding author:

Tel.: +49-621-181-37-54; E-mail: schmid@bwl.uni-mannheim.de.

Address: University of Mannheim, Finance Area, Chair for Business Administration and Corporate Governance, D68131 Mannheim, Germany. 


\section{Introduction}

Recent research questions the finding of a conglomerate discount as reported by Lang and Stulz (1994), Berger and Ofek (1995), and many others. Most prominently, Campa and Kedia (2002) and Villalonga (2004) show that corporate diversification strategies are determined endogenously and when this endogeneity is accounted for, there is no evidence of a conglomerate discount. In another well-known study, Mansi and Reeb (2002) argue that the risk-reducing effect of diversification results in better credit ratings and higher market values of debt. Consequently, the use of the book value of debt in the calculation of firm value may result in an underestimation of firm value in diversified firms. In this paper, we reassess the problems of accounting for the endogeneity of the diversification decision and a potential value transfer from equity to debt holders when estimating the conglomerate discount. ${ }^{1}$

Theory suggests that the combination of business segments with imperfectly correlated earnings streams increases debt capacity through a risk-reducing effect, resulting in better credit ratings and higher market values of debt (e.g., Lewellen, 1971). Hence, while diversification may reduce shareholder value, it should enhance bondholder value due to a reduction in firm risk. Mansi and Reeb (2002) argue that the use of the book value of debt in the calculation of the excess value measure may lead to a downward bias for diversified firms. They underscore this conjecture empirically and show that by replacing the market by the book value of debt in the calculation of the Berger and Ofek (1995) excess value measure the diversification discount disappears.

\footnotetext{
${ }^{1}$ There are various additional attempts to explain the conglomerate discount such as for example (inefficient) crosssubsidizations among divisions of diversified firms (e.g., Shin and Stulz, 1998; Rajan, Servaes, and Zingales, 2000; Whited, 2001; Chevalier, 2004; Ozbas and Scharfstein, 2010), investment inefficiency (e.g., Chen and Chen, 2011), the poor transparency of accounting data produced by conglomerates (e.g., Bushman, Engel, and Smith, 2004), agency problems such as empire building, managerial hubris, managerial overconfidence, and executives' pursuit of insurance to protect the value of their human capital (e.g., Amihud and Lev, 1981; Denis, Denis, and Sarin, 1997; Aggarwal and Samwick, 2003; Holmen, Knopf, and Peterson, 2007; Andreou, Doukas, and Louca, 2010; Hoechle, Schmid, Walter, and Yermack, 2011). For reasons of scope, these alternative explanations are not covered in this paper and we focus on the two most prominent ones.
} 
However, we argue that organizational structure only affects debt value when the degree of diversification increases or decreases. If a firm's degree of diversification remains unchanged, bonds are issued at par and their value does not depend on diversification. Specifically, the strike price, which equals the book value of debt in a contingent claims framework (e.g., Grass, 2010), is not affected by corporate diversification. In contrast, firm risk is expected to decrease when a firm diversifies - provided that the segments' earnings streams are not perfectly correlated. Steady-state corporate diversification has a permanent negative effect on firm risk which is not expected to change as long as the degree of diversification does not change. Hence, at issuance bond (and equity) holders take into account current firm risk which is a function of the diversification status at the time. Only changes in diversification, and consequently firm risk, subsequent to the issuance will affect the respective bond's price and thereby relative price changes between the book and market value of debt. Such effects on debt value will prevail only for a limited period of time as all subsequent bond issues will again be at par. Therefore, the potential effect of risk-reducing diversification on the conglomerate discount is expected to be limited.

We investigate this conjecture empirically based on two alternative approaches to obtain imputed (or implied) market values of debt. The first approach is based on Damodaran (2005) and treats the entire long-term debt on the balance sheet as one coupon bond with the coupon set equal to the interest expenses on all debt. We then value this coupon bond at the current cost of debt for the company approximated by the yield of a bond portfolio with the same credit rating. As Compustat provides an official credit rating from S\&P only for a very limited subset of our sample, we alternatively construct an artificial credit rating based on the interest coverage ratio. Alternatively, we use a similar default risk model as in Jones and Hensher (2004) to obtain credit ratings for all our sample firms. The second approach is based on an implementation of the Merton (1974) bond pricing model which has been used in various previous studies to obtain imputed 
market values of a company (e.g., Eberhart, 2005; Bharath and Shumway, 2008). Glaser and Mueller (2010) show in a contemporaneous study that in their German sample the imputed market values based on the Merton (1974) model are reasonably close to estimates based on traded debt prices for a limited sub-sample which accounts for approximately $13 \%$ of their original sample. The major advantage of our two approaches to obtain imputed the market value of debt is that both do not require data on bond prices for all outstanding bonds of the firms and therefore result in a substantially larger sample size. However, this is at the cost of various potential measurement errors. To mitigate concerns about measurement errors, we use several alternative specifications of the two approaches to obtain an imputed market value of debt.

Our results reveal that, by taking into account the imputed market value of debt in the calculation of the excess value measure, the discount is only slightly reduced and remains significant. Hence, the results are consistent with our conjecture that the risk-reducing effect of diversification on the market value of debt is limited. Only when we use Damodaran's (2005) approach and obtain an imputed market value of debt based on the official credit rating provided by S\&P, the discount turns into a significant premium in all regression specifications. However, we show that this result is caused by the sample selection resulting from the availability of the credit rating from S\&P (26\% of sample firms). This sample selection substantially affects several firm characteristics which might in turn be related to the discount: Firms with S\&P credit ratings available are substantially larger and more likely to be diversified as compared to all sample firms. The results of Mansi and Reeb (2002) may be affected by a similar sample selection problem as their sub-sample including the market value of debt only accounts for roughly $13 \%$ of the total sample.

Following Mansi and Reeb (2002), we also estimate the role of leverage on the conglomerate discount. As the risk-reducing effect of diversification is expected to increase debt value (while reducing shareholder value), the expected downward bias resulting from using the book 
value of debt in the calculation of the excess value measure should increase in leverage. Consistent with Mansi and Reeb (2002), we find that the discount increases in leverage and that there is no conglomerate discount for all-equity firms. This result is inconsistent with our findings based on the imputed market value of debt which indicate a significant conglomerate discount. Possible reasons for this divergence may be that either the conglomerate discount is not caused by a book value of debt bias or that measurement errors in our approaches to obtain an imputed market value of debt erroneously indicate a conglomerate discount.

A potential explanation, which reconciles both findings, is that managers in levered firms become aligned with creditors and reduce firm risk at the expense of the levered shareholders (e.g., Amihud and Lev, 1981). Consequently, the diversification discount only occurs in levered firms and stems from conflicts of interest between managers and shareholders over corporate risk taking. ). In fact, there is a second aspect of our "risk argument" which is that, even without a divergence in book and market values of debt, diversification should result in lower equity values. In a contingent claims framework, equity represents a call option on the firm's assets. Hence, even with steady state diversification the reduced risk in conglomerate firms may result in an equity discount. Consistently, Merton (1973) shows that the value of a portfolio of options is always equal to or higher than the value of an option on the portfolio. The implication of such an option-based explanation of the conglomerate discount would be that the value destruction associated with diversification is due to an agency problem but not necessarily a cross-subsidization of divisions as described in previous research (e.g., Shin and Stulz, 1998; Rajan, Servaes, and Zingales, 2000). Such an explanation is consistent with recent studies investigating the relation between corporate governance and corporate diversification strategies (e.g., Masulis, Wang, and Xie, 2007; Andreou, Doukas, and Louca, 2010; Hoechle, Schmid, Walter, and Yermack, 2011). 
Hence, our paper builds on and extends the argumentation in Mansi and Reeb (2002) and identifies an option effect as the primary channel of the diversification discount.

Two recent papers also investigate the effect of the book value of debt bias on the diversification discount. Grass (2010) uses contingent claims analysis to quantify the effect of riskreducing corporate diversification on the value of equity as a call option on firm assets. He shows that the impact of diversification on firm risk strongly depends on firm size. In contrast to small firms, the risk of large firms does not decline with increasing conglomeration. His analysis shows that the expected equity discount is very low and can even turn into a premium if the path dependency of equity is incorporated. Based on a sample of U.S. firms covering the time period 1984 to 2005, he finds the average expected wealth transfer in all conglomerates to be only 0.63\%. Glaser and Mueller (2010) use alternative specifications of the Merton (1974) bond pricing model to obtain an imputed market value of debt in a sample of non-financial German firms over the time period from 2000 to 2006 . In all specifications, they find the conglomerate discount to be reduced when the market instead of the book value of debt is used. The effect is stronger in pooled OLS than in fixed effects panel regressions. But the estimate of the discount remains economically and statistically significant in all specifications. Consistent with Mansi and Reeb (2002) and our paper, they find no conglomerate discount for mainly equity-financed firms.

The second contribution of this paper is related to methodological issues, in particular the endogeneity of the diversification decision, in estimating the conglomerate discount. Prior literature suggests that corporate diversification strategies are determined endogenously (Campa and Kedia, 2002; Villalonga, 2004) and that if this endogeneity is accounted for, the conglomerate discount disappears. In a first step, we use firm fixed effects to control for potential omitted variables which are either constant over time or constant over firms. This is important if diversified and focused firms systematically differ with respect to various firm characteristics which are ei- 
ther not measurable or not available in the major databases but which are significantly related to firm value. In fact, a robust version of the Hausman (1978) test confirms the presence of firm fixed effects. When we account for firm fixed effects in our standard regression specifications, we find a reduced but still significant conglomerate discount. Second, to relax the assumption that the unobserved heterogeneity that leads to the correlation between the diversification dummy variable and the error term is not constant over time or firms, we control for the endogeneity of the diversification decision by estimating similar instrumental variables regressions and Heckman's (1979) self-selection model as used by Campa and Kedia (2002). These models allow us to account for the fact that firms choose to diversify and to model this endogenous choice based on observed firm and industry characteristics. The results confirm those of Campa and Kedia (2002) in that there is no diversification discount. Finally, we combine the two approaches and add firm fixed effects to the second step of the instrumental variables regressions and Heckman's selfselection model to control for both unobserved firm characteristics and the endogeneity of the diversification decision. The results show a sizable and significant conglomerate discount in the range of $11 \%$ to $21 \%$.

The remainder of the paper is organized as follows. Section II describes the data, sample selection procedure, and main variables. Section III contains the analysis of potential riskreducing effects of diversification and their effect on the calculated excess value measure. Section IV investigates the importance of the estimation technique and addresses potential endogeneity concerns associated with the diversification decision. Finally, Section V concludes. 


\section{Sample selection and variables}

\section{A. Sample selection}

The sample consists of all firms with data reported on both the Compustat Industrial Annual and Segment data files and covers the period from 1985 to 2005 . Following Berger and Ofek (1995) and others, we exclude firm-years in which at least one segment is classified as being in the financial sector (SIC 6000-6999; NAICS 520000-529999) and firm-years with total sales of less than \$20 million. Additionally, we exclude American Depository Receipts (ADRs).

To examine whether diversification increases or decreases corporate value, we rely on the excess value measure of Berger and Ofek (1995). For a firm to be included in our sample, all data necessary to calculate the excess value measure are required (see description below).

\section{B. Measures of excess value}

To examine whether diversification increases or decreases corporate value, we use the excess value measure developed by Berger and Ofek (1995) that compares a firm's value to its imputed value if its segments were operated as stand-alone entities. First, we calculate the imputed value for each segment by multiplying the segment's sales (assets) by the median ratio of market value to sales (assets) for single-segment firms in the same industry. Firm value is defined as the market value of equity plus the book value of debt. In Section III, we will replace the book value of debt by alternative imputed market values of debt. The industry median ratios are based on the narrowest NAICS grouping that includes at least five single-segment firms with complete data and total sales of at least $\$ 20$ million. $^{2}$ Next, the imputed value of the firm is calculated as the sum of the imputed segment values. Finally, the actual excess value measure is calculated as

\footnotetext{
${ }^{2}$ Using sales multipliers, the imputed value for $68.1 \%$ of all segments are based on six-digit NAICS codes, $9.0 \%$ on five-digit NAICS codes, $12.5 \%$ on four-digit NAICS codes, $9.4 \%$ on three-digit NAICS, and $1.0 \%$ on two-digit NAICS codes. The figures for asset multipliers are basically identical.
} 
the log of the ratio of a firm's value to its imputed value. A negative excess value indicates that a firm trades at a discount and a positive excess value implies that the firm trades at a premium.

Some of the segments of diversified firms in our sample have no NAICS codes assigned by Compustat. In contrast, most have a segment name, usually stated as "corporate and other", "eliminations", "corporate and unallocated", or a similar designation. We do not treat these segments separately, but rather attribute their sales (assets) proportionally to the remaining segments in order to sum to the correct figure for the firm's total sales (assets). Nevertheless, for some of the diversified firms in our sample the sum of all segment sales (assets) as provided by the Compustat Segment file disagrees with the respective firm total values from the Compustat Industrial Annual file. We exclude all observations for which the sum of the segment values deviates from the firm's total value by more than $5 \%$. If the absolute deviation is less than $5 \%$, we scale the firm's imputed value up or down by the percentage deviation between the sum of its segments' sales (assets) and total firm sales (assets). Finally, again following Berger and Ofek (1995), we exclude all observations where the actual firm value is either larger than four times the imputed value or less than one fourth of the imputed value. ${ }^{3}$

\section{Measures of diversification}

We use a series of alternative measures of diversification. The first is a dummy variable that is equal to one if a firm reports more than one segment in Compustat's Segments data file. Earlier evidence (e.g., Lang and Stulz, 1994) suggests that firms with two or more segments have a lower firm value than firms with one segment, but that there is no further significant drop in firm value when the number of segments increases from $j$ to $j+1$ segments, where $j \geq 2$. To investigate whether this finding is also valid for our more recent sample, we alternatively use the

\footnotetext{
${ }^{3}$ Throughout the paper, we only report results based on the sales-based excess value measure as the results based on the asset-based measure are qualitatively unchanged.
} 
number of segments reported by Compustat. Additionally, we follow Lang and Stulz, (1994), Comment and Jarrell (1995), and Denis et al. (1997) in using a sales- and asset-based HerfindahlHirshman index (HHI). These HHIs are computed as the sum of the squares of each segment's sales (assets) as a proportion of the square of total sales (assets) for the firm. For example, if a firm has only one segment, its $\mathrm{HHI}$ is equal to one. If a firm has 10 segments that each contribute 10 percent of the sales (assets), its HHI is equal to 0.1 . Hence, the HHI decreases as the degree of diversification increases.

Berger and Ofek (1995) show that only unrelated diversification (i.e., diversification at the two-digit SIC code level) is associated with a significant conglomerate discount while there is no discount for related diversification (i.e., diversification at the four-digit SIC level). We therefore investigate potential differences in the valuation effects associated with related and unrelated diversification. Specifically, we construct a dummy variable which is equal to one if a firm reports more than one segment based on three-digit-level NAICS codes to measure unrelated diversification, and a similar dummy variable, which has a value of one if a firm reports more than one segment based on five-digit-level NAICS codes to measure related diversification.

\section{Sample period and reporting change}

In 1997 the Statement of Financial Accounting Standards (SFAS) 131 superseded SFAS 14 in the regulation of segment reporting (FASB, 1997). At the same time, the Standard Industry Classification (SIC) system was replaced by the North American Industry Classification System (NAICS). As segment reporting under SFAS 14 and SFAS 131 might not be directly comparable, prior studies almost exclusively use pre-1998 data when investigating the conglomerate discount. In this section, we investigate the effect of SFAS 131 on segment reporting and the conglomerate discount and provide several descriptive statistics on our sample. 
Table 1 reports the number of total observations, the percentage of focused firms in the sample, the percentage of diversified firms in the sample, and the mean value of the sales-based excess value measure for focused and diversified firms and each sample calendar year. All firms reporting more than one segment (with differing SIC or NAICS) codes are classified as diversified. Consistent with prior studies based on the pre-1998 sample (e.g., Comment and Jarrell, 1995; Denis et al., 2002), our results indicate a steady trend toward greater focus over the period from 1985 to 1997. Specifically, the percentage of diversified firms drops monotonically from $39.0 \%$ in 1985 to $18.0 \%$ in 1997 . By contrast and consistent with Berger and Hann (2003), the reporting change in 1998 leads to a substantial increase in the percentage of diversified firms in the sample from $18.0 \%$ in 1997 to $26.5 \%$ in 1998 . Hence, segment information under SFAS 131 is in fact more disaggregated and mitigates concerns about segment under-reporting.

Looking at firm valuation, Table 1 shows that the diversification discount is statistically significant at the $1 \%$ level during the complete pre-1998 period and ranges from $6.6 \%$ to $18.0 \%$. Between 1998 and 2002 the discount is substantially reduced (with the exception of 2001) and then becomes large and significant once again in the last three sample years from 2003 to 2005. In addition, we test the equality of medians based on a Wilcoxon signed rank test. The respective results remain basically unchanged as compared to those for the means (not reported in a table) suggesting that the results in Table 1 are unlikely to be caused by outliers. We also check the robustness of the results in Table 1 by estimating cross-sectional regressions of the excess value measure on a dummy variable whether the firm is diversified and the standard set of control variables as proposed by Berger and Ofek (1995) for each sample calendar year. The control variables are: firm size (the log of total assets), capital expenditures standardized by sales, and profitability (EBIT to sales). The results (not reported for space reasons) indicate a significant and substantial conglomerate discount for each sample year in the post-1997 period. 
Next, we investigate the changes in the number of segments, excess value, and the sample composition occurring between 1997 and 1998, when SFAS 14 was replaced by SFAS 131. Table 2 reports the number of observations and the sales-based excess value measure for 1) previously focused firms which become diversified in 1998, 2) diversified firms increasing the number of segments from 1997 to 1998, 3) diversified firms decreasing the number of segments between 1997 and 1998, and 4) previously diversified firms becoming focused in 1998. Most importantly, 378 firms report more segments based on SFAS 131 as compared to SFAS 14 (14\% of all 2,795 firms which are in the sample in 1997 and 1998) while only 99 (4\% of the firms) report less segments. This finding is consistent with Berger and Hann (2003) and confirms that SFAS 131 induces segment reporting on a more disaggregated and presumably more appropriate level. The results also show that increases in the number of segments are associated with a substantial drop in excess value while decreases in the number of segments are accompanied by a reduction of the discount. However, it is difficult to separate changes in the number of segments that are caused by "real" diversification activities and changes caused by the reporting change. As 72 firms undertake acquisitions amounting to $10 \%$ of their sales or more in 1998 , we exclude these observations to obtain a "cleaner" reporting change sample. The results show that the 254 firms becoming diversified with no or only a relatively small acquisition experience a drop in excess value which is comparable to the numbers reported for all firms: from a mean (median) of $-0.07(-0.01)$ to $-0.19(-0.22)$. In contrast, firms undertaking acquisitions experience no decrease in firm value at all and still report a premium in the magnitude of $12 \%$ (13\%) in 1998. Similarly, the 40 diversified firms increasing the number of segments without an acquisition experience a substantial drop in excess value while the 12 firms undertaking at least one acquisition in 1998 show only a slight decrease in the premium. Hence, our results indicate that firms reporting more segments under SFAS 131 and thereby revealing their "true" (or at least more appropriate) level of diversification, experience a substantial increase in the discount. These results are consistent with those 
of Berger and Hann (2003) for a hand-collected sample of 543 firms reporting more than one segment in 1998 based on SFAS 131 as compared to only one segment in 1997 under SFAS $14 .^{4}$

Finally, we compare the conglomerate discount resulting from pooled OLS regressions comparable to those reported in prior research in the post-1997 sample to pre-1998 sample. The choice of control variables is based on Berger and Ofek (1995) and includes the natural logarithm of total assets ( $\ln ($ Assets)), the ratio of capital expenditures to sales (CAPX/Sales), and the ratio of EBIT to sales (EBIT/Sales). In addition, we include the past growth in sales over the last three years (Past Sales Growth) to control for growth opportunities (e.g., see Yermack, 1996). ${ }^{5}$ We estimate pooled cross-sectional time series regressions with Driscoll and Kraay (1998) standard errors, which are heteroskedasticity-consistent and robust to general forms of cross-sectional and temporal dependence. ${ }^{6}$

The results in Columns 1 and 2 of Table 3 compare the results for the pre-1998 and post1997 periods. The results for the pre-1998 period in Column 1 reveal a conglomerate discount in the magnitude of $13.2 \%$, which is very similar to the $13 \%$ obtained by Campa and Kedia (2002) for the 1978 to 1996 period or the $14.4 \%$ obtained by Berger and Ofek (1995) for the 1986 to 1991 period (both based on the sales-based excess value measure). Most importantly, the results

\footnotetext{
${ }^{4}$ Note that the sum of all 1998-firms in Table 2 adds up to 2,966 firms as compared to 3,285 observations reported in Table 1 for 1998. The remaining 319 observations are due to firms with gaps in 1997 either because of missing observations or a violation of one or more of the restrictions applied in the calculation of the excess value measure.

${ }^{5}$ Denis, Denis, and Sarin (1997) and Anderson and Reeb (2003) show that ownership structure is significantly related to the probability that a firm is diversified. Glaser and Mueller (2010) show that the percentage of closely held shares significantly affects the conglomerate discount. When we additionally include the percentage of closely held shares, obtained from Thomson Financial's CDA/Spectrum database, the coefficient on the percentage of closely held shares is always negative and significant and an interaction term between diversification and closely held shares is negative and sometimes significant. We do not include closely held shares in our reported regressions as this reduces samples size by about $25 \%$ while our results remain unchanged.

${ }^{6}$ The results remain qualitatively unchanged when we use the cluster-robust variant of the Huber-White sandwich estimator, which accounts for the dependence of observations within firm-clusters, instead of Driscoll and Kraay (1998) standard errors. Driscoll and Kraay (1998) show that erroneously ignoring cross-sectional dependence in the estimation of linear panel models can lead to severely biased statistical inference. In the context of this study, crosssectional correlation may arise when the decision to diversify of one particular firm is related to or coincides with the decisions of other firms.
} 
in Column 2 show that the discount is only slightly reduced to $11.5 \%$ in the post-1997 period. Not surprisingly, over the full sample period from 1985 to 2005, the discount amounts to nearly 13\% (Column 3). In Column 4, we check the robustness of this result to the inclusion of $R \& D$ expenditures scaled by sales for the post-1997 period. While the coefficient on R\&D expenditures is positive and significant, the conglomerate discount remains basically unchanged. We reestimate the regressions also for the pre-1997 and the full sample period by including R\&D expenditures and find the results to be robust. ${ }^{7}$ In Columns 5 and 6 , we replace the diversification dummy variable by two alternative measures of diversification, the number of segments and a sales-based Herfindahl-Hirshman index. The results are consistent with those in Column 2 and reveal a negative and significant relationship between firm value and the number of segments and a positive relationship between firm value and the concentration of activities over the different segments. Finally, in Columns 7 and 8, we investigate whether the conglomerate discount is largely restricted to unrelated rather than related diversification in the post-1997 sub-sample as suggested by prior research (e.g., Berger and Ofek, 1995). In fact, the results show that only the coefficient on the dummy variable measuring unrelated diversification is statistically significant. Nevertheless, we use the standard definition of the dummy variable in the remainder of the paper to keep our results comparable to those of Campa and Kedia (2002) and others who also use this definition. However, unreported tests show that our results remain qualitatively unchanged when we use the dummy variable based on unrelated diversification.

Summarizing, the results in this section indicate that, although there is evidence of segment underreporting under SFAS 14, the conglomerate discount is largely unaffected by the changes in segment reporting taking place in 1998 and is of similar magnitude in sub-samples

\footnotetext{
${ }^{7}$ As the inclusion of R\&D expenditures substantially reduces the number of observations we henceforth report results from regressions without R\&D expenditures only. However, unreported tests show that the results remain qualitatively similar when R\&D expenditures are included.
} 
from 1985 to 1997 and from 1998 to 2005 . Nevertheless, in the remainder of the paper we only use post-1997 data for two reasons: 1) Data based on one reporting standard seems more consistent and the results obtained from using exclusively post-1997 data can be considered an outof-sample test of prior studies. 2) The introduction of SFAS 131 led to many changes in segment reporting which may affect our econometric analyses in Section IV in which we endogenously model the decision to diversify (e.g., Campa and Kedia, 2002; Villalonga, 2004). ${ }^{8}$

\section{The Conglomerate Discount and Risk Reduction}

In this section, we empirically reassess the value transfer hypothesis of Mansi and Reeb (2002). Mansi and Reeb (2002) rely on the Lehman Brothers Fixed Income database to calculate the market value of debt. This causes three potential problems: First, data is only available for a small subset of the original sample (13\%; i.e., 2,487 out of 18,898 firm-year observations) which might lead to a selection bias. Specifically, larger and more successful firms might have more traded debt outstanding as they are more likely to obtain high credit ratings. Second, many firms have non-traded debt, such as bank debt, which is specified in book value terms but not in market value terms. Third, Mansi and Reeb (2002) have to rely on the book value of debt in focused firms when computing the imputed company values of diversified firms due to the small sample size of firms with traded debt.

We investigate the potential effect of differences between the market and book value of debt on the conglomerate discount based on two alternative approaches which both do not require data on bond prices for all outstanding bonds of the firms and therefore avoid the problem of a substantial reduction of sample size. The first approach is based on Damodaran (2005) and treats the entire long-term debt on the books as one coupon bond with the coupon set equal to the inter-

\footnotetext{
${ }^{8}$ Nevertheless, in unreported tests we check the robustness of our results also for the pre-1998 sample and find all main results to hold.
} 
est expenses on all debt and the maturity set equal to the face value weighted average maturity of the firm's debt. We then value this coupon bond at the current cost of debt for the company. Thus, the market value of the long-term debt is estimated as follows:

$$
\begin{gathered}
\text { Market Value of Long -Term Debt }=\text { Interest Expenses }\left(\frac{1-\frac{1}{(1+\text { Current Cost of Debt })^{\text {Maturity }}}}{1-\frac{1}{(1+\text { Current Cost of Debt })}}\right) \\
+\frac{\text { Book Value of Long }- \text { Term Debt }}{(1+\text { Current Cost of Debt })^{\text {Maturity }}} .
\end{gathered}
$$

To estimate the current cost of debt, we use the yield to a bond portfolio with the same credit rating. As Compustat provides a long-term credit rating (from S\&P) for approximately $22 \%$ of our sample firms only, we calculate "artificial" bond ratings for each sample firm (and year) based on a firm's interest coverage ratio defined as earnings before interest and taxes divided by interest expenses. The interest coverage ratio measures the number of times a company could make its interest payments with its earnings before interest and taxes and therefore proxies for the company's debt burden. To obtain a credit rating for each sample firm, we fit the empirical distribution of the 15,433 firm-year observations (non-financial firms with total sales in excess of $\$ 20$ million) with an official S\&P credit rating on Compustat over our sample period to the calculated interest coverage ratios of the 53,874 firm-year observations with no S\&P credit rating. The yields for the corresponding bond portfolios stem from Bloomberg. ${ }^{9}$ We set the maturity for this long-term debt equal to 10 years. ${ }^{10}$ Finally, we add the book value of short-term debt due in one year to obtain the market value of the firms' debt.

\footnotetext{
${ }^{9} \mathrm{We}$ also calculate an excess value measure based on the official credit rating provided by S\&P and available on Compustat for the limited sub-sample.

${ }^{10}$ Alternatively, we use six years. However, the results remain qualitatively similar and, therefore, we only report results for a maturity of 10 years in the paper.
} 
In this approach, an increase in the credit rating (and the corresponding decrease in the current cost of debt) is associated with a decrease in interest expenses. Consequently, there is a counteracting effect for the valuation of the coupons (interest expenses) which limits the deviations of the market value of debt from the book value of debt. Hence, only unexpected changes in the current cost of debt - such as an improved debt rating due to a diversifying activity which reduces firm risk - affect the value of debt. As a consequence, we expect only a modest reduction in the conglomerate discount when the market value instead of the book value of debt is included in the excess value measure.

Two major problems are associated with this approach. First, S\&P credit ratings on Compustat are available only for three categories of debt: long-term debt, short-term debt, and subordinated debt. Unfortunately, the coverage of short-term debt is even worse than that for long-term debt $(4,702$ firm-years), and there is not one single rating for subordinated debt in our sample of 69,307 firm-years. ${ }^{11}$ Moreover, all S\&P credit ratings on Compustat are "stale", i.e., the ratings are not time-varying and reflect S\&P's current rating of the company at the time of the download (the data is updated quarterly). ${ }^{12}$ Second, for firms with no (long-term) credit rating provided by $\mathrm{S} \& \mathrm{P}$, which is the majority of our sample firm-years, we use only one firm characteristic, the interest coverage ratio to obtain an artificial credit rating.

We attempt to mitigate some of these problems, and check the robustness of our results by estimating credit ratings based on a multi-factor default risk model similar to the one proposed by Jones and Hensher (2004) either for all firm-years with no S\&P long-term credit rating provided by Compustat or alternatively for all firm-years. The default risk model of Jones and Hensher

\footnotetext{
${ }^{11}$ In unreported robustness tests, we adjust the imputed market value of debt by replacing the book value of shortterm debt with an estimate of the market value of short-term debt obtained in the same way as the estimate of the market value of long-term debt. The results remain virtually unchanged.

${ }^{12}$ Consequently, we use the credit ratings as provided by S\&P at the end of our sample period. Firms which leave the sample for one or another reason (e.g., delisting due to a merger, acquisition, or bankruptcy) before the end of our sample period were assigned by Compustat the last rating provided by S\&P before delisting.
} 
(2004) is based on an ordered mixed logit model with fixed and random parameter estimates. The dependent variable in our model is a dummy variable which is equal to one if a firm is indicated in Compustat to be delisted due to bankruptcy and/or liquidation (which is the case for 226 of our sample firms). We use the same set of explanatory variables as Jones and Hensher (2004) and test different model specifications of random effects and standard logit models to identify the statistically significant influences on the default probability. ${ }^{13}$ The obtained default model specification is similar to the one reported in Jones and Hensher (2004; Table 3). We calculate the estimated default probabilities from the random effects logit parameter estimates and obtain the corresponding credit ratings from a translation table provided by S\&P. Then, as before, we obtain yields for the corresponding bond portfolios with the same credit rating from Bloomberg.

The second approach is based on an implementation of the Merton (1974) bond pricing model which has been used in a number of previous studies to estimate the market value of a company (e.g., Eberhart, 2005; Bharath and Shumway, 2008). ${ }^{14}$ For a description of this model, we refer to Eberhart (2005). We use the set of input parameters suggested by Bharath and Shumway (2008) but find the results to remain qualitatively unchanged when we use alternative assumptions such as for example those in Eberhart (2005). ${ }^{15}$

Column 1 of Table 4 reports the results from reestimating the regression equation in Column 2 of Table 3 for the excess value measure including the imputed market value of debt based on the artificial credit rating. As expected, the results show that the conglomerate discount is slightly reduced but remains significant at the $1 \%$ level. In Column 2 , we additionally include

\footnotetext{
${ }^{13}$ The control variables are: net operating cash flow to total assets, cash holdings to total assets, net operating cash flow to annual interest payments, sales to total assets, total debt to total equity, total debt to gross operating cash flow, working capital (current assets - current liabilities) to total assets, and four industry sector dummies.

${ }^{14}$ Eom, Helwege, and Huang (2004) empirically test several structural models of corporate bond pricing and find that more sophisticated structural models do not outperform the simple Merton (1974) model.

${ }^{15}$ The input parameters are: the standard deviation of daily stock returns over the past 125 days, one year time to maturity, the 1-year treasury constant maturity rate, the face value of total debt, and the market capitalization of the company.
} 
leverage and an interaction term between leverage and the diversification dummy variable as control variables. Mansi and Reeb (2002) argue that the expected downward bias resulting from using the book value of debt in the calculation of the excess value measure should increase in leverage. In addition, leverage might affect firm value based on the role of debt in helping to discourage the overinvestment of free cash flow by self-serving managers (e.g., Jensen, 1986; Stulz, 1990; Hart and Moore, 1995; Dang, 2011). Debt can also create value by giving the management an opportunity to signal its willingness to distribute cash flows and to be monitored by lenders. Our results reveal that the conglomerate discount disappears and turns into a slight but insignificant premium. In addition, the coefficient on leverage is estimated negative and significant while the coefficient on the interaction term between leverage and diversification is negative but insignificant.

In Column 3, we check the robustness of these results with respect to the augmented regression specification as proposed by Campa and Kedia (2002) and include their full set of control variables including the log of total assets, the ratio of capital expenditures to sales, and EBIT to sales (each with one and two lags), and the log of total assets squared (the coefficients on the lagged variables and total assets squared are not reported for space reasons). The results show that many of the additional control variables are statistically significant while the diversification dummy variable remains basically unchanged as compared to Column 2. However, the coefficient on leverage becomes insignificant indicating that these additional control variables capture the effect of leverage on firm value.

In Column 4, we include the market value of debt based on the official credit rating provided by $\mathrm{S} \& \mathrm{P}$ in the excess value measure. The results show that the diversification dummy variable turns positive and significant indicating a diversification premium. Moreover, the coefficient on the interaction term between leverage and the diversification dummy variable is estimated 
negative and significant. This latter finding is consistent with Mansi and Reeb (2002) and indicates that the discount increases in leverage. By requiring the availability of the S\&P credit rating and thereby reducing the sample size by roughly $74 \%$ from 16,001 to 4,227 firm-year observations, we might introduce a sample selection bias. Moreover, this sample selection substantially affects several firm characteristics which might be related to the discount. Specifically, firms with S\&P credit ratings available are substantially larger (both the market capitalization and total assets are more than three times higher) and much more likely to be diversified as compared to all sample firms (the percentage of diversified firms is $44 \%$ as compared to $30 \%$ and the average number of segments 1.74 as compared to 1.44$)$. In fact, when we reestimate the regression for the sample for which S\&P ratings are available but use the excess value measure including the book value of debt, the results show a significant premium as well (see Column 5). Consistently, when we alternatively use the excess value measure including the imputed market value of debt based on the artificial credit rating, the diversification dummy variable is estimated to be positive and significant with a coefficient equal to 0.14 and a $t$-value equal to 2.25 (results not reported).

The importance of the sample selection process is confirmed by unreported univariate tests: The sample with $\mathrm{S} \& \mathrm{P}$ ratings available exhibits an average premium for diversified firms (even when the book value of debt is included in the excess value measure) while the mean excess value is between -0.0908 and -0.1157 (depending on the excess value measure) for the larger sample including 17,075 firms with an artificial credit rating. Consequently, we henceforth do not report results on the excess value measure based on the official S\&P credit rating.

In Columns 6, we estimate the role of leverage on the conglomerate discount by estimating the standard regression specification including the excess value measure based on the book value of debt. As in Columns 2 and 3, the diversification dummy variable becomes insignificant. Moreover, consistent with the results in Columns 4 and 5, the coefficient on the interaction term 
between leverage and diversification is estimated negative and significant. Hence, the discount increases in leverage and there is no conglomerate discount for all-equity firms.

In Columns 7 and 8, we use the excess value measure including an imputed market value of debt based on a credit rating which is derived from the credit default predictability model. Consistent with the previous results, we find the conglomerate discount to be somewhat reduced as compared to the specification using the book value of debt, but to remain significant at the $1 \%$ level. In Column 8, the diversification dummy variable turns insignificant and coefficient on the interaction term between leverage and diversification is estimated negative and significant.

Finally, in Columns 9 and 10, we reestimate the regressions in Columns 1 and 2 for the excess value measure including the imputed market value of debt based on the Merton (1974) model. Again the results in Column 9 show that the conglomerate discount, while slightly reduced, remains significant at the $1 \%$ level. When we additionally include leverage and an interaction term between leverage and the diversification dummy variable as additional control variables, the conglomerate discount again disappears and the coefficients on leverage and on the interaction term between leverage and diversification are estimated negative and significant

In summary, the finding of no conglomerate discount for all-equity firms and an increase in the discount in leverage confirms the results of Mansi and Reeb (2002). However, the results are inconsistent with our findings based on the imputed market value of debt which still indicate a discount. This may be either due to the fact that the conglomerate discount is not caused by a book value of debt bias or due to the shortcomings in our approaches to obtain an imputed market value of debt. A potential explanation, which is consistent with both findings, would be that managers in levered firms become aligned with creditors and reduce firm risk at the expense of the levered shareholders (e.g., Amihud and Lev, 1981). In this case, the diversification discount 
would occur in levered firms only and may stem from conflicts of interest between managers and shareholders over corporate risk taking. In fact, a further implication of our "risk argument" is that, even without a divergence in book and market values of debt, diversification should result in lower equity values. As equity represents a call option on the firm's assets, even with steady state diversification the reduced risk in conglomerate firms may result in an equity discount. This is consistent with Merton (1973) who shows that the value of a portfolio of options is always equal to or higher than the value of an option on the portfolio. Consequently, the conglomerate discount is due to an agency problem but not necessarily a cross-subsidization of divisions as described in previous research (e.g., Shin and Stulz, 1998; Rajan, Servaes, and Zingales, 2000). ${ }^{16}$ This explanation is consistent with recent studies investigating the relation between corporate governance and corporate diversification strategies (e.g., Masulis, Wang, and Xie, 2007; Andreou, Doukas, and Louca, 2010; Hoechle, Schmid, Walter, and Yermack, 2011).

\section{Methodological issues in estimating the conglomerate discount}

\section{A. Fixed effects regressions}

In this section, we start by estimating fixed effects regressions to control for potential omitted variables which are either constant over time or constant over firms. Using fixed effects regressions is also potentially important as we argue that organizational structure only affects debt value when the degree of diversification increases or decreases. Hence, we reestimate the analyses in Table 4 by including firm fixed effects. The results are reported in Table $5 .{ }^{17}$ Most importantly, the results show that the diversification dummy variable is negative and significant in all regression specifications. Interestingly, this result also holds for the specifications including

\footnotetext{
${ }^{16}$ We are grateful to an anonymous referee for suggesting this alternative explanation.

${ }^{17}$ For space reasons, we do not report the results for the excess value measure including an imputed market value of debt based on a credit rating which is derived from the logit-based default predictability model. The results are qualitatively identical to those from the two alternative approaches to obtain an imputed market value of debt.
} 
leverage and the interaction term between leverage and diversification. Moreover, the effect of leverage on firm value turns insignificant in Columns 2, 4, and 6 and even positive and significant when the full set of control variables based on Campa and Kedia (2002) is included (Columns 3, 5, and 7). However, when an imputed market values of debt instead of the book value of debt is included in the excess value measure, and additionally leverage and the interaction term between diversification and leverage are included, the conglomerate discount is substantially reduced (Columns 2 to 5) as compared to the specifications which use the book value of debt (Columns 6 and 7) and the specification without leverage and the interaction term between diversification and leverage (Column 1).

We use a Hausman (1978) specification test to test for the presence of firm fixed effects. Although pooled OLS regression yields consistent coefficient estimates when the random effects model is true (i.e., the unobserved effects are uncorrelated with the regressors), its coefficient estimates are inefficient under the null hypothesis of the Hausman test. Because feasible generalized least squares (FGLS) estimation is both consistent and efficient under the null hypothesis of the Hausman test, the coefficient estimates obtained from FGLS should be compared with those of the fixed effects estimator. As the random effects estimator is not fully efficient under the null hypothesis when the unobserved effects or the error term are not i.i.d., we perform the alternative version of the Hausman test based on a Wald test in an auxiliary OLS regression. Wooldridge (2002) recommends to use this version of the test and to estimate the auxiliary regression with robust standard errors to ensure valid inference also when the unobserved effects or the error term are not i.i.d. To assure that the test is robust to heteroskedasticity and general forms of spatial and temporal dependence, we fit the auxiliary regression with Dricoll and Kraay (1998) standard errors. The results of this robust version of the Hausman test are reported in Table 5 and reveal that the random effects assumption is rejected in all seven specifications and consequently firm fixed 
effects should be included in all regressions. When we check the robustness of Table 3 with respect to the inclusion of firm fixed effects, however, the results remain qualitatively unchanged.

\section{B. The endogeneity of the diversification decision}

Recent research suggests that corporate diversification strategies are determined endogenously (e.g., Campa and Kedia, 2002; Villalonga, 2004). In this case it is not possible to assess causation based on the results of OLS regressions as estimated in Tables 3 and 4 (and potentially also Table 5 if the unobserved heterogeneity that leads to the correlation between the diversification dummy variable and the error term is not constant over time or firms). In this section, we first follow Campa and Kedia (2002) and Villalonga (2004) and account for a potential endogeneity of the corporate diversification strategy by estimating instrumental variables regressions as well as Heckman's (1979) self-selection model. Then, we account for the endogeneity of the diversification decision and the relevance of fixed effects by including year and firm fixed effects in the second step of the instrumental variables regressions and Heckman's self-selection model.

We use a Hausman specification test to check for the presence of endogeneity (Hausman, 1978). The test is based on a comparison of the estimator from an instrumental variables regression (which is consistent under both the null and the alternative hypotheses but inefficient under the null hypothesis) and the OLS estimator (which is consistent and efficient under the null hypothesis of no endogeneity but inconsistent under the alternative hypothesis). A key issue is the choice of instruments in the instrumental variables regression as many of the natural instruments for the diversification dummy variable are already included in the excess firm value equation. We rely on Campa and Kedia (2002) and Villalonga (2004) and use various firm, industry, and time characteristics. Firm characteristics are a dummy variable whether the firm is listed on NYSE, Nasdaq, or AMEX, a dummy variable whether the firm belongs to the S\&P industrial index, a dummy variable whether the firm is incorporated outside the U.S., the log of total assets (with 
zero, one, and two lags), EBIT/sales (with zero, one, and two lags), CAPEX/sales (with zero, one, and two lags), and the historical average values of the log of total assets, EBIT/sales, and CAPEX/sales. The set of industry and time characteristics includes the fraction of all firms in an industry which are conglomerates and the fraction of sales by other firms in the industry accounted for by diversified firms, the number and value of merger and acquisition announcements in a given year, and real growth rates of the GDP and its lagged value. ${ }^{18}$ We use four-digit NAICS codes to identify industries (the results are robust to using three- or five-digit NAICS codes). Independent of the choice of control variables and instruments, we can reject the null hypothesis of no endogeneity at the $1 \%$ level which leads us to the conclusion that the diversification dummy variable is in fact endogenously determined.

To account for the endogeneity of diversification, we first estimate an instrumental variables regression where the diversification dummy variable is instrumented. In the first stage, we regress the diversification dummy variable on all presumably exogenous variables in the excess value regression along with the predicted probability of being diversified, which is obtained from a probit regression of the diversification dummy variable on various instruments. ${ }^{19}$ We use the same set of instruments in this probit regression as in the Hausman specification test. In the second stage, we regress the excess value measure on the fitted value from the first stage and control and year dummy variables (not reported in the table). The results are reported in Column 1 of Table 6. Most importantly, the diversification discount decreases substantially and turns insignif-

\footnotetext{
${ }^{18}$ Data on the number and value of M\&A transactions are from Thomson Financial's SDC (Securities Data Corporation) database, and data on GDP growth are from NBER.

${ }^{19}$ We also estimate an alternative model which is based on Campa and Kedia (2002) and uses the predicted probability of diversifying (i.e., a dummy variable which is equal to one when a firm increases the number of segments and zero otherwise) instead of the predicted probability of being diversified in the first-step regressions. As the results are qualitatively similar to those in Columns 1 to 3 of Table 6, we do not report them in a table.
} 
icant. Campa and Kedia (2002) even report a significant premium for the 1978 to 1996 period when using the same instrumental variables setting. ${ }^{20}$

In Column 2, we additionally include firm fixed effects in the second step of the instrumental variables regression. The results show that the conglomerate discount increases and turns statistically significant at the $10 \%$ level. At the same time, the coefficient on leverage turns positive and significant. In Column 3, we do not impose the (nonlinear) functional form of the probit model and use the standard two-stage least squares approach. Hence, in the first step regression, we directly regress the diversification dummy variable on all exogenous variables and instruments (instead of using the predicted probability of being diversified as in Columns 1 and 2). As compared to Column 2, the conglomerate discount in Column 3 further increases to roughly $20 \%$ and is now statistically significant at the $1 \%$ level.

Column 4 reports the results from estimating Heckman's (1979) self-selection model. In the first step, we estimate a probit regression with a dummy variable whether the firm is increasing the number of segments as the dependent variable. The choice of explanatory variables is the same as in the first-step probit regression of the instrumental variables approach. In the second stage, we regress the sales-based excess value measure on the dummy variable whether the firm is diversified, the full set of control variables, and the self-selection parameter (lambda). This lambda parameter (or inverse mills ratio) accounts for the correlation between the error terms in the value equation and the (probit) equation modeling the firms' probability to diversify. The results show that the coefficient on the diversification variable is positive and insignificant while the coefficient on the self-selection parameter is negative and significant. This latter finding indicates the prevalence of self-selection and suggests that characteristics that make firms choose to

\footnotetext{
${ }^{20}$ Campa and Kedia (2002) investigate the decision to diversify and the decision to focus separately and hence restrict the sample either to single-segment and diversifying firms or to single-segment and refocusing firms. When we introduce this same sample partition, the discount is insignificant for both sub-samples (not reported in a table).
} 
diversify are negatively correlated with firm value. Hence, firms with a higher probability of diversifying also tend to be discounted.

In Column 5, we add firm fixed effects to the second step of the Heckman selection model. Again the inclusion of firm fixed effects results in a significant diversification discount while the coefficients on the other variables remain qualitatively similar. To summarize, the results of this section show that by accounting for firm fixed effects, we find a robust and significant conglomerate discount even when the endogeneity of the diversification decision is accounted for in an instrumental variables framework or Heckman's self-selection model.

The results in Table 6 are all based on the excess value measure including the book value of debt. Alternatively, we reestimate all regressions for the excess value measure including an imputed market value of debt. The results are qualitatively similar, with the estimate of the diversification discount somewhat reduced as compared to Table 6 and, therefore, are not reported in a table. We also check the robustness of the results in this section by using alternative explanatory variables in the first-stage regressions of the instrumental variables regressions (e.g., including past sales growth or omitting several of the variables originally included) and by varying the instruments. We also use an alternative industry definition based on three-digit NAICS codes and repeat the analysis for the asset-based excess value measure (including the book value of debt or the market value of debt based on the artificial credit rating). However, the results change only immaterially (for brevity we do not report them in a table).

We also corroborate our findings by testing whether firms that diversify already trade at a discount prior to the diversification, or whether their value decreases as a result of the diversification. If diversified firms already trade at a discount before they diversify, this indicates that it is not diversification that causes the discount but that diversification might be a firm's reaction to 
poor performance. Our results show that previously focused firms that diversify at some point during our sample period do not trade at a discount in the years before diversification. In contrast, focusing firms trade at a very large discount before they decrease the number of segments in which they were active, or become completely focused. This finding suggests that the increase in focus may be due to external pressure (e.g., by active shareholders). ${ }^{21}$

A potential concern with the results in our study is that the documented diversification discount may be due to conglomerates purchasing discounted target firms rather than diversification itself (e.g., Graham et al., 2002). To check whether this causes our results, we reestimate the regressions reported in Tables 3 to 6 by excluding 1) all firm-years in which an acquisition takes place or alternatively 2) all firm-years for which an acquisition takes place over respective or the past three years. In all cases, the results (not reported for space reasons) remain qualitatively unchanged although the sample is substantially reduced under the second exclusion restriction.

\section{Conclusion}

This paper contributes to the literature on the conglomerate discount in two ways. First, we investigate whether diversification has a risk-reducing effect and if such risk effects affect the conglomerate discount. We argue that an increase (decrease) in the value of debt can occur only when diversification increases (decreases). If a firm's degree of diversification remains unchanged, bonds are issued at par and their value does not change - unless market rates change, of course. This, however, is not related to the diversification decision of the firms. Hence, differences in debt value can only emerge when a firm changes the degree of diversification. Even then, they will prevail only for a limited period of time as all subsequent bonds will again be issued at par reflecting the degree of diversification of the firm and the resulting consequences on firm risk.

\footnotetext{
${ }^{21}$ These results are not reported in the paper for space reasons but are available from the authors upon request.
} 
Consequently, we expect the potential effect on the conglomerate discount to be limited. In fact, when we replace the book value of debt by several alternative imputed market values of debt in the calculation of the excess value measure, the discount - although somewhat reduced - remains statistically significant. Our results also show that the discount increases in leverage and that there is no conglomerate discount at all for all-equity firms. This latter finding is consistent with the value transfer hypothesis of Mansi and Reeb (2002) and therefore seems inconsistent with our finding of a conglomerate discount even when using an imputed market value of debt in the excess value measure. A potential explanation, which is consistent with both findings, is that managers in levered firms become aligned with creditors and reduce firm risk at the expense of the levered shareholders. In fact, even without a divergence in book and market values of debt, diversification should result in lower equity values. As equity represents a call option on the firm's assets, even with steady state diversification the reduced risk in conglomerate firms may result in an equity discount. Hence, the conglomerate discount may be due to an agency problem but not a cross-subsidization of divisions as described in previous research (e.g., Shin and Stulz, 1998; Rajan, Servaes, and Zingales, 2000). Such an explanation is consistent with recent studies investigating the relation between corporate governance and corporate diversification (e.g., Masulis, Wang, and Xie, 2007; Hoechle, Schmid, Walter, and Yermack, 2011).

Second, we investigate the role of the estimation technique on the documented conglomerate discount. Specifically, we use a robust version of the Hausman (1978) specification test to demonstrate the importance of accounting for firm fixed effects when estimating the conglomerate discount. If we include firm fixed effects in our standard regression specifications, the conglomerate discount remains statistically and economically significant. This finding is consistent with Campa and Kedia (2002). Alternatively, we account for a potential endogeneity of the diversification decision in an instrumental variables framework or by estimating a Heckman (1979) 
selection model as proposed by Campa and Kedia (2002) and Villalonga (2004). If firm fixed effects are neglected, the conglomerate discount in fact disappears as reported in these two studies. However, if firm fixed effects are included, the conglomerate discount is estimated to be statistically significant and in the magnitude of $11 \%$ to $21 \%$. Hence, our findings reopen the (re-)search for alternative explanations for the conglomerate discount or the reason for why so many firms diversify or remain diversified if diversification destroys so much value. 


\section{References}

Ahn, S., Denis, D.J., Denis, D.K., 2006. Leverage and investment in diversified firms. Journal of Financial Economics 79, 317-337.

Aggarwal, R.K., Samwick, A.A., 2003. Why do managers diversify their firms? Agency reconsidered. Journal of Finance 58, 71-118.

Amihud, Y., Lev, B., 1981. Risk reduction as a managerial motive for conglomerate mergers. Bell Journal of Economics 12, 605-617.

Anderson, R.C., Reeb, D.M., 2003. Founding-family ownership, corporate diversification, and firm leverage. Journal of Law and Economics 46, 653-684.

Andreou, P.C., Doukas, J.A., Louca, C., 2010. Managerial overconfidence and the diversification discount. Working Paper, Cyprus University of Technology.

Berger, P.G., Hann, R.N., 2003. The impact of SFAS No. 131 on information and monitoring. Journal of Accounting Research 41, 163-223.

Berger, P.G., Ofek, E., 1995. Diversification's effect on firm value. Journal of Financial Economics 37, 39-65.

Bharath, S.T., Shumway, T., 2008, Forecasting default with the Merton distance to default model, Review of Financial Studies 21, 1339-1369.

Bushman, R., Engel, E., Smith, A., 2004. Financial accounting information, organizational complexity and corporate governance systems. Journal of Accounting and Economics 37, 167-201.

Campa, J.M., Kedia, S., 2002. Explaining the diversification discount. Journal of Finance 57, 1731-1762.

Chen, S.-S., and I.J. Chen, 2011, Inefficient investment and the diversification discount: Evidence from corporate asset purchases, Journal of Business Finance and Accounting, forthcoming.

Chevalier, J., 2004. What do we know about cross-subsidization? Evidence from merging firms. Advances in Economic Analysis \& Policy 4, Issue 1, 1-27.

Comment, R., Jarrell, G.A., 1995. Corporate focus and stock returns. Journal of Financial Economics $37,67-87$.

Damodaran, A., 2005. Applied corporate finance: A user's manual, 2nd ed., New York, NY: John Wiley and Sons.

Dang, V.A., 2011, Leverage, debt maturity and firm investment: An empirical analysis. Journal of Business Finance and Accounting 38, 225-258.

Denis, D.J., Denis, D.K., Sarin, A., 1997. Agency problems, equity ownership, and corporate diversification. Journal of Finance 52, 135-160.

Denis, D.J., Denis, D.K., Yost, K., 2002. Global diversification, industrial diversification, and firm value. Journal of Finance 57, 1951-1979. 
Driscoll, J.C., Kraay, A.C., 1998. Consistent covariance matrix estimation with spatially dependent panel data. Review of Economics and Statistics 80, 549-560.

Eberhart, A.C., 2005, A comparison of Merton's option pricing model of corporate debt valuation to the use of book values, Journal of Corporate Finance 11, 401-426.

Eom, Y.H., Helwege, J., Huang, J.-Z., 2004, Structural models of corporate bond pricing: An empirical analysis, Review of Financial Studies 17, 499-544.

Financial Accounting Standards Board. Statement of Financial Accounting Standards No. 131: Disclosures about Segments of an Enterprise and Related Information, Norwalk, CT: FASB (1997).

Glaser, M., Mueller, S., 2010. Is the diversification discount caused by the book value bias of debt? Journal of Banking and Finance 34, 2307-2317.

Graham, J., Lemmon, M., Wolf, J.G., 2002. Does corporate diversification destroy value? Journal of Finance 57, 695-720.

Grass, G., 2010. The impact of conglomeration on the option value of equity. Journal of Banking and Finance 34, 3010-3024.

Hausman, J., 1978. Specification tests in econometrics. Econometrica 46, 1251-1271.

Hart, O., Moore, J., 1995. Debt and seniority - An analysis of the role of hard claims in constraining management. American Economic Review 85, 567-585.

Heckman, J., 1979. Sample selection bias as specification error. Econometrica 47, 153-161.

Hoechle, D., Schmid, M., Walter, I., Yermack, D., 2011, How much of the diversification discount can be explained by poor corporate governance? Journal of Financial Economics, forthcoming.

Holmen, M., Knopf, J.D., and S. Peterson, 2007, Trading-off corporate control and personal diversification through capital structure and merger activity, Journal of Business Finance and Accounting 34, 1470-1495.

Jensen, M.C., 1986. Agency costs of free cash flow, corporate finance and takeovers. American Economic Review 76, 323-329.

Jones, S., Hensher, D.A., 2004. Predicting firm financial distress: A mixed logit model, Accounting Review 79, 1011-1038.

Laeven, L., Levine, R., 2007. Is there a diversification discount in financial conglomerates? Journal of Financial Economics 85, 331-367.

Lang, L.H.P., Stulz, R.M., 1994. Tobin's q, corporate diversification, and firm performance. Journal of Political Economy 102, 1248-1280.

Lewellen, W., 1971. A pure financial rationale for the conglomerate merger. Journal of Finance 26, 521-537. 
Lichtenberg, F.R., 1991. The managerial response to regulation of financial reporting for segments of a business enterprise. Journal of Regulatory Economics 3, 241-249.

Mansi, S.A., Reeb, D.M., 2002. Corporate diversification: What gets discounted? Journal of Finance 57, 2167-2183.

Masulis, R.W., Wang, C., Xie, F., 2007. Corporate governance and acquirer returns. Journal of Finance 62, 1851-1889.

McConnell, J., Servaes, H., 1995. Equity ownership and the two faces of debt. Journal of Financial Economics 39, 131-157.

Merton, R.C., 1973. Theory of rational option pricing, Bell Journal of Economics and Management Science 4, 141-183.

Merton, R.C., 1974. On the pricing of corporate debt: The risk structure of interest rates. Journal of Finance 29, 449-470.

Ozbas, O., and Scharfstein, D.S., 2010. Evidence on the dark side of internal capital markets. Review of Financial Studies 23, 581-599.

Rajan, R., Servaes, H., Zingales, L., 2000. The cost of diversity: The diversification discount and inefficient investment. Journal of Finance 55, 35-80.

Schmid, M.M., Walter, I., 2009. Do financial conglomerates create or destroy economic value? Journal of Financial Intermediation 18, 193-216.

Shin, H.-H., Stulz, R.M., 1998, Are internal capital markets efficient? Quarterly Journal of Economics 113, 531-552.

Stulz, R.M., 1990. Managerial discretion and optimal financing policies. Journal of Financial Economics 26, 3-27.

Villalonga, B., 2004. Does diversification cause the diversification discount? Financial Management 33, 5-27.

White, H., 1980. A Heteroskedasticity-Consistent Covariance Matrix Estimator and a Direct Test for Heteroskedasticity. Econometrica 48, 817-838.

Whited, T., 2001. Is it inefficient investment that causes the diversification discount? Journal of Finance 56, 1667-1691.

Wooldridge, J.M., 2002. Econometric analysis of cross section and panel data, Cambridge, MA: MIT Press.

Yermack, D., 1996. Higher market valuation of companies with a small board of directors. Journal of Financial Economics 40, 185-211. 


\section{Table 1: Excess Value of Focused and Diversified Firms by Calendar Year}

The table reports the number of total observations $(N)$, the percentage of focused firms in the sample, the percentage of diversified firms in the sample, and the mean values of the sales-based excess value measure for focused and diversified firms for each sample calendar year. All firms reporting more than one segment (with differing SIC or NAICS) codes are classified as diversified. The equality of means is tested using a standard $t$ test. $* * * / * * / *$ denotes statistical significance at the $1 \% / 5 \% / 10 \%$ level.

\begin{tabular}{|c|c|c|c|c|c|c|}
\hline Year & N & Focused (\%) & Excess Value & Diversified (\%) & Excess Value & Difference \\
\hline 1985 & 2,510 & $61.00 \%$ & 0.0101 & $39.00 \%$ & -0.1697 & $0.1798 * * *$ \\
\hline 1986 & 2,573 & $62.84 \%$ & -0.0054 & $37.16 \%$ & -0.1455 & $0.1401^{* * *}$ \\
\hline 1987 & 2,737 & $66.75 \%$ & 0.0040 & $33.25 \%$ & -0.0883 & $0.0924^{* * *}$ \\
\hline 1988 & 2,688 & $68.15 \%$ & -0.0032 & $31.85 \%$ & -0.0836 & $0.0805^{\text {*** }}$ \\
\hline 1989 & 2,559 & $70.14 \%$ & 0.0067 & $29.86 \%$ & -0.0839 & $0.0906^{* * *}$ \\
\hline 1990 & 2,468 & $71.39 \%$ & 0.0051 & $28.61 \%$ & -0.0739 & $0.0790 * * *$ \\
\hline 1991 & 2,509 & $73.34 \%$ & -0.0146 & $26.66 \%$ & -0.1073 & $0.0927^{* * *}$ \\
\hline 1992 & 2,755 & $75.03 \%$ & -0.0100 & $24.97 \%$ & -0.0761 & $0.0662^{* * *}$ \\
\hline 1993 & 3,109 & $77.39 \%$ & 0.0015 & $22.61 \%$ & -0.1131 & $0.1146^{* * *}$ \\
\hline 1994 & 3,432 & $78.41 \%$ & -0.0017 & $21.59 \%$ & -0.1247 & $0.1230^{\star * *}$ \\
\hline 1995 & 3,680 & $79.70 \%$ & -0.0092 & $20.30 \%$ & -0.1045 & $0.0953^{* \star *}$ \\
\hline 1996 & 3,990 & $81.30 \%$ & -0.0058 & $18.70 \%$ & -0.1101 & $0.1043^{* * *}$ \\
\hline 1997 & 4,100 & $81.95 \%$ & -0.0133 & $18.05 \%$ & -0.1118 & $0.0985^{* * *}$ \\
\hline 1998 & 3,285 & $73.49 \%$ & -0.0528 & $26.51 \%$ & -0.0749 & 0.0221 \\
\hline 1999 & 2,995 & $69.12 \%$ & -0.0658 & $30.88 \%$ & -0.1048 & $0.0391^{*}$ \\
\hline 2000 & 2,920 & $70.79 \%$ & -0.0499 & $29.21 \%$ & -0.0999 & 0.0500 * \\
\hline 2001 & 2,759 & $72.82 \%$ & -0.0271 & $27.18 \%$ & -0.1028 & $0.0757^{* * *}$ \\
\hline 2002 & 2,709 & $73.24 \%$ & -0.0090 & $26.76 \%$ & -0.0409 & 0.0319 \\
\hline 2003 & 2,602 & $73.21 \%$ & 0.0033 & $26.78 \%$ & -0.1175 & $0.1209^{* * *}$ \\
\hline 2004 & 2,762 & $72.27 \%$ & 0.0161 & $27.73 \%$ & -0.1042 & $0.1203^{* * *}$ \\
\hline 2005 & 2,523 & $70.91 \%$ & -0.0022 & $29.09 \%$ & -0.1398 & $0.1376^{* * *}$ \\
\hline
\end{tabular}


Table 2: What happens between 1997 and $1998 ?$

The table reports the mean and median excess value based on sales (including the book value of debt) of the firms which are in the sample in 1997 and 1998 and change the number of segments between 1997 and 1998 for 1) previously focused firms diversifying, 2) diversified firms increasing the number of segments, 3) diversified firms decreasing the number of segments, and 4) previously diversified firms becoming focused. Median values are in parentheses and the number of observations in square brackets.

\begin{tabular}{|c|c|c|c|c|}
\hline \multirow[b]{2}{*}{ Previously focused firms diversifying } & \multicolumn{2}{|c|}{1997} & \multicolumn{2}{|c|}{1998} \\
\hline & $\begin{array}{r}-0.023 \\
(0.000)\end{array}$ & [326] & $\begin{array}{r}-0.122 \\
(-0.157)\end{array}$ & [326] \\
\hline $\begin{array}{l}\text { Diversified firms increasing the number } \\
\text { of segments }\end{array}$ & $\begin{array}{r}-0.088 \\
(-0.097)\end{array}$ & {$[52]$} & $\begin{array}{r}-0.145 \\
(-0.248)\end{array}$ & [52] \\
\hline $\begin{array}{l}\text { Diversified firms decreasing the number } \\
\text { of segments }\end{array}$ & $\begin{array}{r}-0.087 \\
(-0.039)\end{array}$ & [59] & $\begin{array}{r}-0.068 \\
(-0.011)\end{array}$ & [43] \\
\hline $\begin{array}{l}\text { Previously diversified firms becoming } \\
\text { focused }\end{array}$ & $\begin{array}{r}-0.199 \\
(-0.306)\end{array}$ & {$[40]$} & $\begin{array}{r}-0.108 \\
(-0.167)\end{array}$ & [40] \\
\hline
\end{tabular}




\section{Table 3: Pooled OLS regressions of the sales-based excess value measure for different sample periods}

The table reports estimates from pooled cross-sectional time series regressions of the excess value measure based on sales (including the book value of debt) on different measures of diversification and control variables. The dummy variable measuring unrelated diversification (Column 7) is equal to one if a firm is diversified at the threedigit level and the dummy variable measuring related diversification (Column 8) is equal to one if a firm is diversified at the five- or six-digit level only. Year dummy variables are included in all regressions but are not reported. The $t$-values (in parentheses) are based on Driscoll and Kraay standard errors which are heteroskedasticityconsistent and robust to general forms of cross-sectional and temporal dependence. $* * * / * * / *$ denotes statistical significance at the $1 \% / 5 \% / 10 \%$ level.

\begin{tabular}{|c|c|c|c|c|c|c|c|c|}
\hline \multicolumn{9}{|c|}{ Dependent Variable: Excess Value Measure Based on Sales (Including the Book Value of Debt) } \\
\hline \multirow[t]{2}{*}{ Sample Period: } & $1985-1997$ & $1998-2005$ & $1985-2005$ & $1998-2005$ & $1998-2005$ & 1998-2005 & $1998-2005$ & 1998-2005 \\
\hline & (1) & (2) & (3) & (4) & (5) & (6) & (7) & (8) \\
\hline \multirow[t]{2}{*}{ Constant } & $-0.497^{\star \star \star}$ & -0.596 *** & $-0.552^{* * *}$ & $-0.680^{* * *}$ & $-0.540^{* * *}$ & $-0.877^{\text {***}}$ & $-0.596^{* * *}$ & $-0.593^{* * *}$ \\
\hline & $(-26.786)$ & $(-12.167)$ & $(-19.300)$ & $(-12.095)$ & $(-10.070)$ & $(-32.947)$ & $(-12.141)$ & $(-12.149)$ \\
\hline \multirow[t]{2}{*}{ Diversified } & $-0.132^{\text {*** }}$ & $-0.115^{\text {***}}$ & $-0.128^{\text {*** }}$ & $-0.118^{* * *}$ & & & & \\
\hline & $(-20.292)$ & $(-6.715)$ & $(-15.612)$ & $(-5.078)$ & & & & \\
\hline \multirow[t]{2}{*}{ Number of Segments } & & & & & $-0.075^{* * *}$ & & & \\
\hline & & & & & $(-8.845)$ & & & \\
\hline \multirow[t]{2}{*}{ Herfindahl Index (Sales) } & & & & & & $0.270^{* * *}$ & & \\
\hline & & & & & & $(7.563)$ & & \\
\hline \multirow[t]{2}{*}{ Diversified (unrelated) } & & & & & & & $-0.096 * * *$ & \\
\hline & & & & & & & $(-5.881)$ & \\
\hline \multirow[t]{2}{*}{ Diversified (related) } & & & & & & & & -0.039 \\
\hline & & & & & & & & $(-1.126)$ \\
\hline \multirow[t]{2}{*}{ In(Assets) } & $0.062^{* * *}$ & $0.085^{* * *}$ & $0.075^{* * *}$ & $0.091^{\star \star *}$ & $0.088^{* \star *}$ & $0.086^{* * *}$ & $0.083^{* * *}$ & $0.078^{* * *}$ \\
\hline & $(17.929)$ & $(11.975)$ & $(13.483)$ & $(7.945)$ & $(12.522)$ & $(12.236)$ & $(11.251)$ & $(10.277)$ \\
\hline \multirow[t]{2}{*}{ CAPEX/Sales } & $0.408^{* * *}$ & $0.246^{* * *}$ & $0.340^{* * *}$ & $0.496^{\star * *}$ & $0.243^{\star \star *}$ & $0.245^{* * *}$ & $0.253^{* * *}$ & $0.264^{* * *}$ \\
\hline & $(6.887)$ & $(4.945)$ & $(6.349)$ & $(4.704)$ & $(5.059)$ & $(5.032)$ & $(5.138)$ & $(5.420)$ \\
\hline \multirow[t]{2}{*}{ EBIT/Sales } & $0.903^{* * *}$ & $0.132^{*}$ & $0.370^{* *}$ & $0.395^{* * *}$ & 0.130 * & 0.130 * & 0.130 * & $0.127^{*}$ \\
\hline & $(7.103)$ & $(1.958)$ & $(2.498)$ & (3.365) & $(1.920)$ & $(1.907)$ & $(1.906)$ & $(1.807)$ \\
\hline \multirow[t]{2}{*}{ Past Sales Growth } & $0.043^{* \star *}$ & $0.062^{* * *}$ & $0.054^{* \star *}$ & $0.081^{* * *}$ & $0.062^{* * *}$ & $0.062^{* * *}$ & $0.063^{* * *}$ & $0.065^{* * *}$ \\
\hline & $(3.716)$ & $(23.552)$ & $(5.766)$ & $(10.769)$ & (22.566) & (23.203) & $(22.404)$ & $(20.763)$ \\
\hline R\&D/Sales & & & & $\begin{array}{c}0.756 \text { *** } \\
(7.366)\end{array}$ & & & & \\
\hline $\mathrm{N}$ & 30,224 & 19,529 & 49,753 & 11,598 & 19,529 & 19,515 & 19,529 & 19,529 \\
\hline Firms & 5,773 & 5,094 & 7,746 & 3,052 & 5,094 & 5,093 & 5,094 & 5,094 \\
\hline R-squared & 0.131 & 0.090 & 0.101 & 0.137 & 0.092 & 0.090 & 0.087 & 0.083 \\
\hline
\end{tabular}




\section{Table 4: Pooled OLS regressions of the sales-based excess value measure (1998-2005)}

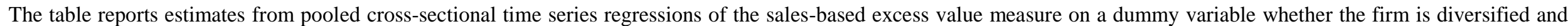

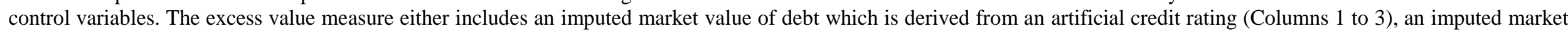

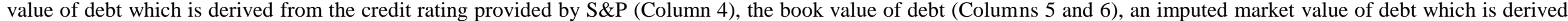
from a default risk model similar to the model proposed by Jones and Hensher (2004) (Columns 7 and 8), or an imputed market value of debt which is based on the Merton (1974)

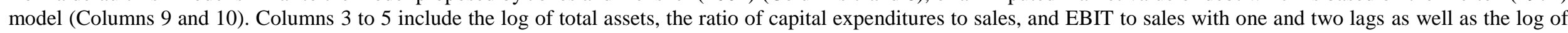

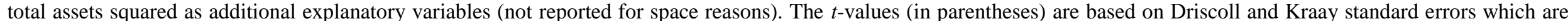
heteroskedasticity-consistent and robust to general forms of cross-sectional and temporal dependence. $* * * * * / *$ denotes statistical significance at the $1 \% / 5 \% / 10 \%$ level.

Dependent Variable: Excess Value Measure Based on Sales Including the:

\begin{tabular}{|c|c|c|c|c|c|c|c|c|c|c|}
\hline & \multicolumn{3}{|c|}{ Market Value of Debt (Art. Rating) } & \multirow{2}{*}{$\frac{M V D(S \& P)}{(4)}$} & \multicolumn{2}{|c|}{ Book Value of Debt } & \multicolumn{2}{|c|}{ MVD (Default Prob. Model) } & \multicolumn{2}{|c|}{ MVD (Merton Model) } \\
\hline & (1) & (2) & (3) & & (5) & (6) & (7) & (8) & (9) & $(10)$ \\
\hline Constant & $\begin{array}{c}-0.517^{\text {*** }} \\
(-14.882)\end{array}$ & $\begin{array}{c}-0.488^{* * *} \\
(-16.569)\end{array}$ & $\begin{array}{c}-0.860^{* * *} \\
(-10.178)\end{array}$ & $\begin{array}{l}-0.751 \text { *** } \\
(-5.541)\end{array}$ & $\begin{array}{l}-0.711^{\text {*** }} \\
(-4.346)\end{array}$ & $\begin{array}{c}-0.584^{\star * *} \\
(-13.032)\end{array}$ & $\begin{array}{l}-0.480^{* * *} \\
(-8.824)\end{array}$ & $\begin{array}{c}-0.518^{* * *} \\
(-10.312)\end{array}$ & $\begin{array}{l}-0.584^{* * *} \\
(-8.493)\end{array}$ & $\begin{array}{l}-0.629^{* * *} \\
(-8.699)\end{array}$ \\
\hline Diversified & $\begin{array}{l}-0.088^{\text {*** }} \\
(-6.769)\end{array}$ & $\begin{array}{r}0.007 \\
(0.116)\end{array}$ & $\begin{array}{r}0.012 \\
(0.223)\end{array}$ & $\begin{array}{l}0.190^{* * *} \\
(3.371)\end{array}$ & $\begin{array}{l}0.092^{\star \star \star} \\
(4.921)\end{array}$ & $\begin{array}{r}0.010 \\
(0.484)\end{array}$ & $\begin{array}{l}-0.078^{\star * *} \\
(-4.642)\end{array}$ & $\begin{array}{r}0.035 \\
(1.537)\end{array}$ & $\begin{array}{l}-0.095^{\star \star \star} \\
(-6.697)\end{array}$ & $\begin{array}{r}0.039 \\
(1.527)\end{array}$ \\
\hline $\ln ($ Assets $)$ & $\begin{array}{c}0.069^{* * *} \\
(13.578)\end{array}$ & $\begin{array}{c}0.071^{* * *} \\
(15.623)\end{array}$ & $\begin{array}{c}0.479 \text { *** } \\
(11.034)\end{array}$ & $\begin{array}{l}0.412^{* * *} \\
(8.536)\end{array}$ & $\begin{array}{l}0.409^{* * *} \\
(8.350)\end{array}$ & $\begin{array}{c}0.088^{* * *} \\
(13.446)\end{array}$ & $\begin{array}{l}0.068^{\star * *} \\
(9.536)\end{array}$ & $\begin{array}{l}0.080^{* * *} \\
(9.305)\end{array}$ & $\begin{array}{l}0.087^{* * *} \\
(7.577)\end{array}$ & $\begin{array}{l}0.094^{* * *} \\
(8.007)\end{array}$ \\
\hline CAPEX/Sales & $\begin{array}{l}0.192^{\text {***}} \\
(4.016)\end{array}$ & $\begin{array}{l}0.193^{\text {***}} \\
(4.027)\end{array}$ & $\begin{array}{l}0.095^{\text {***}} \\
(3.037)\end{array}$ & $\begin{array}{r}0.029 \\
(0.661)\end{array}$ & $\begin{array}{l}-0.174^{\star \star \star} \\
(-5.782)\end{array}$ & $\begin{array}{l}0.246^{\star * *} \\
(4.943)\end{array}$ & $\begin{array}{l}0.177^{\star \star \star} \\
(5.213)\end{array}$ & $\begin{array}{l}0.177^{\star * *} \\
(5.127)\end{array}$ & $\begin{array}{l}0.243^{\star \star \star} \\
(4.639)\end{array}$ & $\begin{array}{l}0.241^{\star \star \star} \\
(4.646)\end{array}$ \\
\hline EBIT/Sales & $\begin{array}{l}0.159^{* \star *} \\
(2.810)\end{array}$ & $\begin{array}{l}0.137^{* * *} \\
(2.713)\end{array}$ & $\begin{array}{l}0.103^{* *} \\
(2.036)\end{array}$ & $\begin{array}{l}0.455^{* * *} \\
(3.452)\end{array}$ & $\begin{array}{l}0.316^{* \star \star} \\
(3.120)\end{array}$ & $\begin{array}{c}0.115^{\star} \\
(1.880)\end{array}$ & $\begin{array}{r}0.159 \\
(1.503)\end{array}$ & $\begin{array}{r}0.135 \\
(1.399)\end{array}$ & $\begin{array}{r}0.114 \\
(1.485)\end{array}$ & $\begin{array}{r}0.107 \\
(1.433)\end{array}$ \\
\hline Past Sales Growth & $\begin{array}{l}0.054^{* * *} \\
(8.123)\end{array}$ & $\begin{array}{l}0.052^{* * *} \\
(8.105)\end{array}$ & & & & $\begin{array}{c}0.061^{* * *} \\
(24.356)\end{array}$ & $\begin{array}{l}0.065^{* * *} \\
(5.128)\end{array}$ & $\begin{array}{l}0.062^{* * *} \\
(5.838)\end{array}$ & $\begin{array}{c}0.074^{\star * *} \\
(15.781)\end{array}$ & $\begin{array}{c}0.073^{\star * *} \\
(17.645)\end{array}$ \\
\hline Leverage & & $\begin{array}{c}-0.073^{*} \\
(-1.758)\end{array}$ & $\begin{array}{r}-0.038 \\
(-0.947)\end{array}$ & $\begin{array}{l}-0.492^{* * *} \\
(-7.194)\end{array}$ & $\begin{array}{r}0.054 \\
(1.239)\end{array}$ & $\begin{array}{l}-0.061^{\star *} \\
(-2.319)\end{array}$ & & $\begin{array}{r}-0.067 \\
(-1.489)\end{array}$ & & $\begin{array}{c}-0.061^{*} \\
(-1.687)\end{array}$ \\
\hline DiversifiedLeverage & & $\begin{array}{r}-0.161 \\
(-1.317)\end{array}$ & $\begin{array}{r}-0.162 \\
(-1.503)\end{array}$ & $\begin{array}{l}-0.382^{* * *} \\
(-5.080)\end{array}$ & $\begin{array}{l}-0.233^{\text {***}} \\
(-8.269)\end{array}$ & $\begin{array}{l}-0.222^{\star \star *} \\
(-3.790)\end{array}$ & & $\begin{array}{l}-0.421^{\star * *} \\
(-8.378)\end{array}$ & & $\begin{array}{l}-0.273^{\text {***}} \\
(-8.904)\end{array}$ \\
\hline $\mathrm{N}$ & 16,379 & 16,379 & 16,001 & 4,227 & 4,227 & 19,528 & 12,624 & 12,624 & 15,178 & 15,178 \\
\hline Firms & 4,546 & 4,546 & 4,440 & 898 & 898 & 5,094 & 3,301 & 3,301 & 3,791 & 3,791 \\
\hline R-squared & 0.060 & 0.073 & 0.100 & 0.121 & 0.066 & 0.099 & 0.053 & 0.082 & 0.090 & 0.097 \\
\hline
\end{tabular}


Table 5: Fixed effects regressions of the sales-based excess value measure (1998-2005)

The table reports estimates from fixed effects regressions of the sales-based excess value measure on a dummy variable whether the firm is diversified and control variables. All regressions include firm-fixed effects. The excess value measure either includes an imputed market value of debt which is derived from an artificial credit rating (Columns 1 to 3), an imputed market value of debt which is based on the Merton (1974) model (Columns 4 and 5), or the book value of debt (Columns 6 and 7). The $t$-values (in parentheses) are based on Driscoll and Kraay standard errors which are heteroskedasticity-consistent and robust to general forms of cross-sectional and temporal dependence. The reported Hausman test compares the estimates from fixed effects regressions to those from random effects regressions and is robust to heteroskedasticity and general forms of spatial and temporal dependence. ***/**/* denotes statistical significance at the $1 \% / 5 \% / 10 \%$ level.

\begin{tabular}{|c|c|c|c|c|c|c|c|}
\hline & \multicolumn{3}{|c|}{ Market Value of Debt (Art. Rating) } & \multicolumn{2}{|c|}{ MV of Debt (Merton model) } & \multicolumn{2}{|c|}{ Book Value of Debt } \\
\hline & (1) & (2) & (3) & (4) & (5) & (6) & (7) \\
\hline Constant & $\begin{array}{l}-0.578^{* \star \star} \\
(-5.024)\end{array}$ & $\begin{array}{l}-0.568^{\star \star \star} \\
(-4.325)\end{array}$ & $\begin{array}{l}-0.633^{* * \star} \\
(-3.748)\end{array}$ & $\begin{array}{l}-1.097^{\star \star \star} \\
(-7.016)\end{array}$ & $\begin{array}{l}-1.268^{\star \star \star} \\
(-4.402)\end{array}$ & $\begin{array}{l}-1.065^{\star \star \star} \\
(-7.814)\end{array}$ & $\begin{array}{l}-1.159^{\star * \star} \\
(-6.518)\end{array}$ \\
\hline Diversified & $\begin{array}{c}-0.112^{* * *} \\
(-5.514)\end{array}$ & $\begin{array}{l}-0.067^{* *} \\
(-2.301)\end{array}$ & $\begin{array}{c}-0.047^{*} \\
(-1.795)\end{array}$ & $\begin{array}{c}-0.065^{*} \\
(-1.913)\end{array}$ & $\begin{array}{c}-0.045^{*} \\
(-1.709)\end{array}$ & $\begin{array}{l}-0.120^{* * *} \\
(-5.095)\end{array}$ & $\begin{array}{l}-0.122^{\star * *} \\
(-5.183)\end{array}$ \\
\hline $\ln ($ Assets $)$ & $\begin{array}{l}0.068^{* * *} \\
(3.744)\end{array}$ & $\begin{array}{l}0.066^{\star \star *} \\
(3.295)\end{array}$ & $\begin{array}{l}0.513^{* * *} \\
(9.257)\end{array}$ & $\begin{array}{l}0.155^{\star \star *} \\
(6.031)\end{array}$ & $\begin{array}{l}0.713^{\star \star \star} \\
(7.604)\end{array}$ & $\begin{array}{l}0.150^{\star \star \star} \\
(6.755)\end{array}$ & $\begin{array}{c}0.647^{\star \star \star} \\
(10.628)\end{array}$ \\
\hline CAPEX/Sales & $\begin{array}{l}0.302^{* * *} \\
(3.589)\end{array}$ & $\begin{array}{l}0.301^{* * *} \\
(3.580)\end{array}$ & $\begin{array}{l}0.166^{* * *} \\
(2.710)\end{array}$ & $\begin{array}{l}0.350^{* * *} \\
(6.022)\end{array}$ & $\begin{array}{l}0.233^{* * *} \\
(6.249)\end{array}$ & $\begin{array}{l}0.322^{* * *} \\
(6.486)\end{array}$ & $\begin{array}{l}0.197^{\star \star *} \\
(7.025)\end{array}$ \\
\hline EBIT/Sales & $\begin{array}{c}0.163^{* * *} \\
(2.649)\end{array}$ & $\begin{array}{l}0.161^{* * *} \\
(2.641)\end{array}$ & $\begin{array}{r}0.060 \\
(1.213)\end{array}$ & $\begin{array}{l}0.177^{* * *} \\
(4.820)\end{array}$ & $\begin{array}{r}0.052 \\
(1.305)\end{array}$ & $\begin{array}{c}0.154^{\star * *} \\
(5.088)\end{array}$ & $\begin{array}{c}0.049^{*} \\
(1.819)\end{array}$ \\
\hline Past Sales Growth & $\begin{array}{l}0.014^{* * *} \\
(4.008)\end{array}$ & $\begin{array}{l}0.014^{* * *} \\
(3.980)\end{array}$ & & $\begin{array}{l}0.018^{* * *} \\
(3.782)\end{array}$ & & $\begin{array}{l}0.018^{* * *} \\
(4.085)\end{array}$ & \\
\hline In(Assets) (1 lag) & & & $\begin{array}{l}-0.234^{\text {*** }} \\
(-22.458)\end{array}$ & & $\begin{array}{l}-0.289^{* * *} \\
(-47.751)\end{array}$ & & $\begin{array}{l}-0.254^{* * *} \\
(-22.910)\end{array}$ \\
\hline CAPEX/Sales (1 lag) & & & $\begin{array}{l}0.086^{* *} \\
(2.374)\end{array}$ & & $\begin{array}{l}0.068^{* * *} \\
(7.066)\end{array}$ & & $\begin{array}{c}0.095^{* * *} \\
(6.146)\end{array}$ \\
\hline EBIT/Sales (1 lag) & & & $\begin{array}{r}0.018 \\
(0.457)\end{array}$ & & $\begin{array}{l}-0.031^{* *} \\
(-2.392)\end{array}$ & & $\begin{array}{l}-0.036^{\star \star \star} \\
(-2.796)\end{array}$ \\
\hline In(Assets) (2 lags) & & & 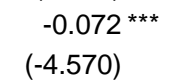 & & $\begin{array}{l}-0.090^{* * *} \\
(-5.068)\end{array}$ & & $\begin{array}{l}-0.090^{\text {*** }} \\
(-6.386)\end{array}$ \\
\hline CAPEX/Sales (2 lags) & & & $\begin{array}{r}0.015 \\
(0.732)\end{array}$ & & $\begin{array}{l}0.042^{* * *} \\
(5.592)\end{array}$ & & $\begin{array}{c}0.044^{* * *} \\
(10.605)\end{array}$ \\
\hline EBIT/Sales (2 lags) & & & $\begin{array}{l}0.040^{* * *} \\
(3.427)\end{array}$ & & $\begin{array}{r}0.005 \\
(0.238)\end{array}$ & & $\begin{array}{r}0.014 \\
(0.743)\end{array}$ \\
\hline In(Assets) squared & & & $\begin{array}{l}-0.021^{\text {*** }} \\
(-8.481)\end{array}$ & & $\begin{array}{l}-0.024^{* * *} \\
(-3.400)\end{array}$ & & $\begin{array}{l}-0.022^{\star \star \star} \\
(-5.558)\end{array}$ \\
\hline Leverage & & $\begin{array}{r}-0.001 \\
(-0.055)\end{array}$ & $\begin{array}{l}0.029^{* * *} \\
(2.938)\end{array}$ & $\begin{array}{r}0.006 \\
(0.805)\end{array}$ & $\begin{array}{l}0.041^{\text {***}} \\
(4.614)\end{array}$ & $\begin{array}{r}0.008 \\
(1.288)\end{array}$ & $\begin{array}{c}0.043^{\star * *} \\
(7.676)\end{array}$ \\
\hline DiversifiedLeverage & & $\begin{array}{l}-0.077^{\text {** }} \\
(-1.973)\end{array}$ & $\begin{array}{l}-0.104^{\star \star *} \\
(-2.827)\end{array}$ & $\begin{array}{l}-0.286^{* * \star} \\
(-4.242)\end{array}$ & $\begin{array}{l}-0.312^{\star \star \star} \\
(-4.759)\end{array}$ & $\begin{array}{r}-0.016 \\
(-0.345)\end{array}$ & $\begin{array}{r}-0.002 \\
(-0.029)\end{array}$ \\
\hline $\mathrm{N}$ & 16,379 & 16,379 & 16,001 & 15,178 & 14,826 & 19,528 & 19,044 \\
\hline Firms & 4,546 & 4,546 & 4,440 & 3,791 & 3,719 & 5,094 & 4,982 \\
\hline $\begin{array}{l}\text { Hausman test } \\
\text { ( } p \text {-value) }\end{array}$ & $\begin{array}{l}83.09^{* * *} \\
(0.000)\end{array}$ & $\begin{array}{l}1389.50 \text { *** } \\
(0.000)\end{array}$ & $\begin{array}{l}114.67^{* * *} \\
(0.000)\end{array}$ & $\begin{array}{l}382.62^{* * *} \\
(0.000)\end{array}$ & $\begin{array}{l}688.36^{* * *} \\
(0.000)\end{array}$ & $\begin{array}{l}803.42^{* * *} \\
(0.000)\end{array}$ & $\begin{array}{l}240.48^{* * *} \\
(0.000)\end{array}$ \\
\hline R-squared & 0.030 & 0.031 & 0.068 & 0.045 & 0.102 & 0.055 & 0.111 \\
\hline
\end{tabular}


Table 6: Instrumental variables regressions and Heckman's self selection model of the sales-based excess value measure (1998-2005)

The table reports the estimates from instrumental variables (IV) regressions and Heckman's (1979) self-selection model of the excess value measures based on sales on a dummy variable whether the firm is diversified and control variables. The excess value measure is based on the book value of debt. The first step of the IV regressions in Columns 1 and 2 uses all exogenous variables along with the estimated probability of diversifying whereas the latter is based on a probit regression of the diversification dummy variable on a set of firm-, industry- and timespecific instruments. Column 3 reports the results from a standard two-stage least squares regression. The first step of Heckman's self-selection model consists of a probit regression of a dummy variable whether the firm increases the number of segments on the same firm-, industry- and time-specific instruments as used in the IV regression whereas the sample is restricted to single-segment firms and all diversifying firms. Lambda is the selfselection parameter. Columns 1 and 4 include year dummy variables which are not reported. Columns 2, 3 and 5 include firm-fixed effects and report the within R-squared (Columns 2 and 3). Note that the S\&P 500 dummy variable is dropped in Columns 2, 3 and 5 as there is no time-series variation in this variable. The $t$-values in Columns 1, 2, 3, and 5 (in parentheses) are based on Driscoll and Kraay standard errors which are heteroskedasticity-consistent and robust to general forms of cross-sectional and temporal dependence. $* * * / * * / *$ denotes statistical significance at the $1 \% / 5 \% / 10 \%$ level.

Dependent Variable: Excess Value Measure Based on Sales (Including the Book Value of Debt)

(1)

\begin{tabular}{|c|c|c|c|c|c|}
\hline & & & & & \\
\hline \multirow[t]{2}{*}{ Constant } & $-1.284^{* * *}$ & $-1.175^{* * *}$ & $-1.154^{* * *}$ & $-1.325^{* * *}$ & $-1.118^{* * *}$ \\
\hline & $(-17.607)$ & $(-6.578)$ & $(-6.497)$ & $(-4.551)$ & $(-6.116)$ \\
\hline \multirow[t]{2}{*}{ Diversified } & -0.081 & $-0.123^{*}$ & $-0.207^{\star \star *}$ & 0.022 & $-0.114^{\star * *}$ \\
\hline & $(-1.418)$ & $(-1.769)$ & $(-2.875)$ & $(0.449)$ & $(-5.779)$ \\
\hline \multirow[t]{2}{*}{ In(Assets) } & $0.666^{* * *}$ & $0.653^{* * *}$ & $0.650^{* * *}$ & $0.618^{* * *}$ & $0.705^{\star \star *}$ \\
\hline & $(23.757)$ & $(10.589)$ & (10.589) & $(6.941)$ & $(9.267)$ \\
\hline \multirow[t]{2}{*}{ CAPEX/Sales } & $0.114^{\star \star *}$ & $0.191^{\star * *}$ & $0.192^{* * *}$ & 0.100 & $0.210^{* * *}$ \\
\hline & (3.916) & $(7.131)$ & $(6.824)$ & $(0.415)$ & $(7.008)$ \\
\hline \multirow[t]{2}{*}{ EBIT/Sales } & $0.105^{\star \star \star}$ & 0.045 & 0.044 & 0.075 & -0.004 \\
\hline & $(3.020)$ & $(1.627)$ & $(1.583)$ & $(0.474)$ & $(-0.126)$ \\
\hline \multirow[t]{2}{*}{ In(Assets) (1 lag) } & $-0.157^{* * *}$ & $-0.260^{\star * *}$ & $-0.261^{* * *}$ & $-0.286^{* * *}$ & $-0.279^{\star * *}$ \\
\hline & $(-7.594)$ & $(-24.824)$ & $(-25.454)$ & $(-3.643)$ & $(-25.145)$ \\
\hline \multirow[t]{2}{*}{ CAPEX/Sales (1 lag) } & $0.096^{* * *}$ & $0.094^{* * *}$ & $0.089^{* * *}$ & -0.043 & $0.113^{\star * *}$ \\
\hline & $(3.787)$ & $(5.281)$ & $(5.019)$ & $(-0.143)$ & $(6.231)$ \\
\hline \multirow[t]{2}{*}{ EBIT/Sales (1 lag) } & $-0.061^{* * *}$ & $-0.033^{* *}$ & $-0.032^{* *}$ & -0.146 & $-0.052^{* \star *}$ \\
\hline & $(-3.352)$ & $(-2.556)$ & $(-2.450)$ & $(-0.625)$ & $(-3.632)$ \\
\hline \multirow[t]{2}{*}{ In(Assets) (2 lags) } & $-0.168^{* * *}$ & $-0.084^{* * *}$ & $-0.082^{* * *}$ & $-0.107^{\star *}$ & $-0.106^{\star \star *}$ \\
\hline & $(-11.000)$ & $(-5.900)$ & $(-5.693)$ & $(-2.035)$ & $(-6.303)$ \\
\hline \multirow[t]{2}{*}{ CAPEX/Sales (2 lags) } & $0.041^{* *}$ & $0.043^{* * *}$ & $0.045^{* \star *}$ & $0.354^{* * *}$ & $0.063^{* * *}$ \\
\hline & $(1.992)$ & $(8.925)$ & (9.009) & (2.899) & $(5.094)$ \\
\hline \multirow[t]{2}{*}{ EBIT/Sales (2 lags) } & $-0.037^{* *}$ & 0.015 & 0.018 & $0.535^{* \star *}$ & $0.033^{\star *}$ \\
\hline & $(-2.075)$ & $(0.925)$ & $(1.035)$ & $(2.871)$ & $(2.272)$ \\
\hline \multirow[t]{2}{*}{ In(Assets) squared } & $-0.023^{* \star *}$ & $-0.022^{* * *}$ & $-0.022^{* \star *}$ & $-0.013^{* *}$ & $-0.028^{\star \star *}$ \\
\hline & $(-11.213)$ & $(-5.567)$ & $(-5.463)$ & $(-2.324)$ & $(-4.699)$ \\
\hline \multirow[t]{2}{*}{ S\&P 500 Dummy } & $0.228^{* \star *}$ & & & $0.174^{* *}$ & \\
\hline & $(6.296)$ & & & $(2.112)$ & \\
\hline \multirow[t]{2}{*}{ Leverage } & -0.020 & $0.044^{* * *}$ & $0.044^{* * *}$ & $-0.264^{* * *}$ & $-0.068^{* *}$ \\
\hline & $(-0.515)$ & $(7.876)$ & $(7.904)$ & $(-3.551)$ & $(-2.189)$ \\
\hline \multirow[t]{2}{*}{ Lambda } & & & & $-0.185^{\star \star}$ & $-0.086^{\star * *}$ \\
\hline & & & & $(-2.204)$ & $(-3.655)$ \\
\hline $\mathrm{N}$ & 18,947 & 18,947 & 18,947 & 16,702 & 16,702 \\
\hline Firms & 4,959 & 4,959 & 4,959 & 4,350 & 4,350 \\
\hline R-squared & 0.142 & 0.108 & 0.108 & - & - \\
\hline Firm fixed effects & no & yes & yes & no & yes \\
\hline Estimation Methodology & IV & IV & IV & Self-select & Self-select \\
\hline
\end{tabular}

